\title{
Around the World in Less Than a Day: Virtual Reality, Destination Image and Perceived Destination Choice Risk in Family Tourism.
}

\section{Ryan Yung}

Department of Tourism, Sport and Hotel Management, Griffith University, Brisbane, Australia

https://orcid.org/0000-0003-3755-2557

Corresponding Author: ryan.yung@griffithuni.edu.au

Catheryn Khoo-Lattimore

Department of Tourism, Sport and Hotel Management, Griffith University, Brisbane, Australia

https://orcid.org/0000-0003-2858-870X

Girish Prayag

UC Business School, University of Canterbury, Christchurch, New Zealand

https://orcid.org/0000-0001-6243-2747

Ekaterina Surovaya

UC Business School, University of Canterbury, Christchurch, New Zealand

Word count: 8110 


\begin{abstract}
There is growing recognition for the potential benefits of utilising Virtual Reality (VR) in destination marketing. Conceptual papers suggested the technology's increased immersion, interactivity, and visualisation would translate well into advancing the avenues of information dissemination to potential consumers. However, empirical research on the effects of VR on consumer behaviour is still limited despite rapidly increasing interest from the tourism industry. The purpose of this study is to explore the influence of VR on destination image and perceived destination choice risk for family tourism. Data was collected from 48 members of 12 families who experienced VR through the Samsung Gear VR headset. They were then interviewed as whole family groups. The findings suggest that VR positively influenced both destination image and reduced perceived destination choice risk, with stronger cognitive and affective components of destination image attributed to the immersive experiences. Participants elicited both cognitive and affective components of destination image used in post-visit studies just from the virtual experience pre-visit. Managerial implications include recommendations for VR content tailored to families instead of generic VR experiences as part of DMOs targeting strategies for this segment.
\end{abstract}

Keywords: Virtual Reality, Destination Image, Family Tourism, Destination Marketing, Perceived Risk 


\subsection{Introduction}

The internet, as well as innovations in technology has affected perceptions and consumptions of tourism destinations (Govers, Go, \& Kumar, 2007). One such technological innovation that has increasingly grown in importance and interest is Virtual Reality (VR). Early conceptual papers on VR postulated potential applications for the technology, positing that the depth and extension of sensory participation would alter and expand the avenues of information dissemination (Cranford, 1996; Zhai, 1998). In tourism, where informative communication of intangible products has always been vital (Huang, Backman, Backman, \& Chang, 2016), the impending arrival of VR ranged from being hailed as a new horizon (Hobson \& Williams, 1995), to virtual threats (Cheong, 1995). Research has shown that destination marketing organisations (DMO) online platforms containing informative, involving, and interactive media were more effective in directly influencing perceived destination image; increasing interest and subsequent intention to visit (Burgess, Parish, \& Alcock, 2011; Choi, Ok, \& Choi, 2016; Molinillo, Liébana-Cabanillas, Anaya-Sánchez, \& Buhalis, 2018). As an advancement of interactive media, previous research has continually postulated VR's potential as an effective information communication tool (Guttentag, 2010; Mikropoulos \& Strouboulis, 2004; Steuer, 1992). Virtual tours enable the dissemination of rich information, improving the quality of destination image formation through portraying not only the physical characteristics of the destination but also the experience of being there (Cho, Wang, \& Fesenmaier, 2002). Hyun and O'Keefe (2012) similarly found that virtual information such as 3D tours positively influence destination image by allowing consumers to feel like they were at the destination, providing a detailed preview. Unsurprisingly, since then, there has been a growing number of studies examining the impact of VR on the customer purchase journey (Flavián, Ibáñez-Sánchez, \& Orús, 2019a), attitude and behaviour change toward destinations (Flavián, Ibáñez-Sánchez, \& Orús, 2019b; Marasco, Buonincontri, van Niekerk, Orlowski, \& Okumus, 2018; Tussyadiah, 
Wang, Jung, \& tom Dieck, 2018), as well as acceptance of VR technology for travel planning (Disztinger, Schlögl, \& Groth, 2017; Huang et al., 2016). Based on the limited number and exploratory nature of these empirical studies on VR's role as a marketing tool for tourism sites (Marasco et al., 2018; Marchiori, Niforatos, \& Preto, 2018), gaps in literature remain around use-cases, target groups, methodology and the various dimensions surrounding consumer behaviour and experience using VR (Beck, Rainoldi, \& Egger, 2019; Wei, 2019). Methodwise, there remains a lacuna of research on the effects of using VR in group settings; a natural use-case for family travel decision-making (Schänzel \& Yeoman, 2015b). Based on Beck et al. (2019)'s review of VR literature, only one study, a conference paper, has ever used group interviews with VR (see Tussyadiah, Wang, \& Jia, 2016). Also, despite calls from outside tourism (ICT, cyberpsychology) for more qualitative research on VR (North \& North, 2016; Thie \& van Wijk, 1998), there are only two other qualitative studies on immersive VR; both conference papers (Jung, tom Dieck, Moorhouse, \& tom Dieck, 2017; Pantelidis, tom Diek, Jung, \& Miller, 2018).

Therefore, this study is exploratory in nature with the objective of identifying how VR can be used as a marketing tool for DMOs to reduce travel planning risk for families with children. It is framed in the context of group destination selection by families. The group destination selection approach is important as it more naturally reflects the dynamics of family travel planning. Incorporating concepts from destination image, perceived risk, and family travel will provide better understanding of the trade-offs that families make in travel planning. This will in turn provide important insights into how using VR could assist families in navigating these trade-offs. Utilising a substantive and theory-based approach will also allow for a clearer understanding of how and why VR is useful as an information dissemination option for destination marketers over, or in conjunction with, traditional visual mediums; providing a foundation for future research and development into the optimal adaptation of VR in a tourism 
marketing context.

\subsection{Literature Review}

\subsection{VR Research in Tourism}

VR's potential in the various sub-sectors of tourism is evident (see Yung \& Khoo-Lattimore, 2017). Whether it is in the context of education (Deale, 2013; Huang, Backman, Chang, Backman, \& McGuire, 2013), marketing (Huang et al., 2016; Pantano \& Servidio, 2011; Tussyadiah et al., 2018), cultural heritage (Dueholm \& Smed, 2014; tom Dieck \& Jung, 2015) or sustainability (Han, Hwang, \& Woods, 2014; Pearlman \& Gates, 2010), the technology offers unprecedented novel and interactive avenues for dissemination of information. Facets of VR have already been adopted by the tourism industry. For examples, Destination BC (2014) in British Columbia, Canada and Tourism Australia (2016) both have VR experiences available on their websites.

Researchers have also postulated a multitude of potential usages for VR in the tourism industry. Studies have suggested that VR's greatest strength is its ability to visualise spatial environments (Guttentag, 2010). This is especially crucial in tourism where products are intangible and are confidence goods which consumers are not able to test in advance. Putting on a VR headset and being able to compare different destinations could help consumers make informed decisions (Cheong, 1995). Wan, Tsaur, Chiu, and Chiou (2007) found that virtual experiences provided more effective advertising compared to brochures for theme parks due to the richness and interactivity of the information. This is supported by studies that show the ultimate goal for web-based destination marketing is to provide travel information to tourists via a vicarious destination experience to persuade them to visit (Huang et al., 2016). However, studies to-date on innovation in tourism, and more specifically VR, have mainly been applied research, akin to prototyping (Hjalager, 2010; Yung \& Khoo-Lattimore, 2017); prompting calls 
for research in the area to be more substantive and theory-based (Hjalager, 2010; Huang et al., 2016). This paper attempts to address this call by exploring VR through combining concepts from destination image and perceived risk in the family tourism context. The relevant concepts will be expanded on in the following sub-sections.

\subsection{The Role of VR in Destination Image}

Destination image is an important concept in understanding tourists' destination selection process (Baloglu \& McCleary, 1999) and is generally accepted as a mental representation of the destination in an individual's mind (del Bosque \& Martín, 2008; Kock, Josiassen, \& Assaf, 2016). Destination image is made up of cognitive (awareness and knowledge) and affective (feelings) evaluations of the place and is formed by both consumer characteristics and stimulus factors (Baloglu \& McCleary, 1999; Echtner \& Ritchie, 1993; Gallarza, Saura, \& García, 2002; MacKay \& Fesenmaier, 1997; Stepchenkova \& Mills, 2010). Finally, the action step is the conative component and refers to how consumers act on the information; often described as being analogous to behaviour (Agapito, Oom do Valle, \& da Costa Mendes, 2013; Gartner, 1994; Kladou \& Mavragani, 2015; Pike \& Ryan, 2004). del Bosque and Martín (2008) found that a favourable destination image has positive effects on the individual's beliefs of a future experience. More importantly, they posited that after establishing a favourable destination image, the destination occupies a privileged position in the individual's selection process. For DMOs, who rarely have a product to sell in their role of matching buyers and sellers, information integration and brokerage is especially important to ensure the destination is differentiated in the minds of targeted markets. (Palmer \& McCole, 2000).

At the same time, one of the biggest challenges DMOs face is understanding and searching for the latest technologies that will revolutionise interaction with information (Gretzel, Fesenmaier, Formica, \& O'Leary, 2006). Considering research has suggested that VR can 
enable rich information (cognitive) as well as enjoyment (affective), exploring the influence of VR from the lens of destination image formation will provide important insights to DMOs (Cho et al., 2002). Tourists gain cognitive information pre-visit through multiple channels, such as word-of-mouth, television, brochures, or the Web (Liu, 2005). Of that content, visual mediums have been found to be the most significant contributors to destination image (MacKay \& Fesenmaier, 1997; Mariani, Di Felice, \& Mura, 2016). VR, being a progression of the visual medium, has the potential to offer more information-rich data, contributing towards the cognitive and subsequently, affective components. Cognitively, VR research has shown that the higher immersive visual display as well as increased interactivity results in more positive transfer of information when used in simulation-based training (Stevens \& Kincaid, 2015; Vora et al., 2002), e-commerce (Li, Daugherty, \& Biocca, 2002; Suh \& Lee, 2005), and education (Durl, Dietrich, Pang, Potter, \& Carter, 2017; Mikropoulos \& Natsis, 2011). Affectively, VR's higher levels of telepresence have been shown to illicit more intense anxiety and relaxation (Gorini, Griez, Petrova, \& Riva, 2010; Riva et al., 2007; Villani, Repetto, Cipresso, \& Riva, 2012), enjoyment and fun (Lau \& Lee, 2012), and fear (Meehan, Razzaque, Insko, Whitton, \& Brooks, 2005) when compared to traditional media. Although these studies were not from tourism literature, their results suggest that VR could contribute in enhancing both the cognitive and affective components when transferred to a destination image context, consequently enhancing the conative component. Considering destination marketing has the role of providing information as well as image building for a destination, VR has a role to play in enhancing destination image and facilitating dissemination and comprehension of information related to destinations.

\subsection{Perceived Destination Choice Risk}

Information also plays a key role in the management of perceived risk related to destination 
choice for DMOs. Consumers perceive risk as the uncertainty and potentially undesirable consequences of a purchase (Lim, 2003). All risk is posited to stem from performance risk as the risk of the product not being as advertised, which leads to the perception of financial, time and psychosocial loss (Featherman \& Pavlou, 2003). Tourism research has shown that as the perceived risk of visiting a destination increases, tourist attitudes toward visiting that destination become more negative (Quintal, Lee, \& Soutar, 2010). Hence, the importance of providing rich information to the consumer, reducing perceived risk and uncertainty in the product and consequently increasing confidence (Anderson, 1981; Berger \& Mitchell, 1989; Lim, 2003). Unsurprisingly, higher quality of information on DMO websites has been shown to positively influence users' intention to visit the destination (Chung, Lee, Lee, \& Koo, 2015).

Tourists consider rich information essential as this reduces risk and offsets uncertainty in their travel planning (Gursoy \& McCleary, 2004; Slevitch \& Sharma, 2008). Wong and Yeh (2009) supported this, finding that once tourists really understand a destination, the influence of risk perception is reduced; tourists then have increased certainty regarding visiting the destination and experience less hesitation in making associated decisions. Tying into destination image literature, the importance of establishing a positive destination image is also a key factor in reducing perceived destination choice risk. Chew and Jahari (2014) found that tourists who had a firmly developed positive image of Japan were not influenced by the physical risk of revisiting the country post-Fukushima Disaster. The opposite is also found by Lepp, Gibson, and Lane (2011), where destinations with negative images are perceived to be higher in risk, even if tourists know little about the destination. Crucially, the same study found that using vibrant images and informative text on a well-designed website induced a more positive image, significantly reducing perceived destination choice risk for their participants. With the suggestion that VR can provide the complex information that consumers respond positively to (Gammack \& Hodkinson, 2003), exploring if the technology can indeed improve on the effort 
of traditional media to induce positive images and reduce perceived destination choice risk would bring interesting insights. Yet, to-date, such studies remain absent in tourism literature.

\subsection{VR for Family Tourism}

From the consumer point of view, if VR is being positioned as a risk reduction tool due to the ability to vicariously experience aspects the destination before getting there (Guttentag, 2010; Huang et al., 2016; Zhai, 1998), then it can be argued that its impact can be considerably higher on the family rather than individual decision-making process (Shaw, 1997). In families where children do not contribute to the financial expenses of travel, the perceived travel planning risk increases due to the bigger financial outlay (Featherman \& Pavlou, 2003). Research has shown that the decision-making process in families is more complex when compared to the solo traveller, often requiring more extensive information before selecting a destination (Kozak \& Duman, 2012; Litvin, Xu, \& Kang, 2004; Schänzel \& Yeoman, 2015b; Therkelsen, 2010; Thomson, Laing, \& McKee, 2007). Earlier research has specifically examined the role of husband and wife in family vacation decision-making (Bronner \& de Hoog, 2008; Jenkins, 1978; Litvin et al., 2004). This discussion saw scholars agree that a joint-decision making process is engaged in the family context, where the two partners in a relationship, "engage in social power through compromising, bargaining, coercing or persuading one another that result in both parties making the decision" (Khoo-Lattimore, Prayag, \& Cheah, 2015, p. 514).

Another stream of family tourism research saw included the arguments on the presence of children in family travel. A handful of studies purported that children have very little or no influence on the holiday decision process (e.g. Filiatrault \& Ritchie, 1980; Foxman, Tansuhaj, \& Ekstrom, 1989), while a growing number of recent studies evidence the contrary (e.g. KhooLattimore, del Chiappa, \& Yang, 2018; Li, Xu, \& Chen, 2020). Accordingly, there is also an increasing demand to understand the generational differences between the needs of children 
and their parents, or even grandparents as families begin to function more democratically (Schänzel \& Yeoman, 2015a; Yang, Khoo-Lattimore, \& Yang, 2020). The impact of children on the family decision-making process have been found to vary, depending on the products and services, family characteristics, family communication environment, age of child and stage of the decision making process (Gram, 2005; Kang \& Hsu, 2005; Therkelsen, 2010). Some studies confirm increased decision influence with age (e.g. Howard \& Madrigal, 1990; Wang, Hsieh, Yeh, \& Tsai, 2004) while others show the contrary (e.g. Bronner \& de Hoog, 2008; Darley \& Lim, 1986). There is also little consensus on parents' perceptions of how their children impact the various vacation decision-making stages (Nanda, Hu, \& Bai, 2007). While we do know that children typically influence family travel itineraries (Khoo-Lattimore et al., 2015; Thornton, Shaw, \& Williams, 1997) and types of activities (Jenkins, 1978; KhooLattimore \& Yang, 2020; Wu, Wall, Zu, \& Ying, 2019; Yang et al., 2020), we do not know if and how VR may change these findings. In addition, while we so far know that 'child friendly' marketing offers (Bronner \& de Hoog, 2008) impact family decision-making process by reducing their increasing vacation value and minimising financial risks, we have no understanding of how VR may contribute to reducing perceived destination choice risk for families. To date, the only literature linking VR and family travel is Whittington (2015)'s future scenarios paper on family travels in 2050. Empirical VR research on families as a target group remains absent. Hypothetically however, inducing a positive destination image and reducing perceived risk in destination choice through VR is more important for families compared to solo and even friend group travel, due to the bigger investment of time and money required (Featherman \& Pavlou, 2003; Kozak \& Duman, 2012).

\subsection{Summary and Research Questions}

Based on the literature reviewed, VR has potential to emerge as the next technological 
advancement for DMOs influencing consumer behaviour. The unprecedented expansion in information dissemination is proposed to be most valuable to travelling families, where decision-making and the need for reducing perceived destination choice risk has been found to be more complex compared to the solo traveller. However, there is little empirical evidence and theory-based research on the influence of VR on family consumer behaviour in the context of destination marketing. Consequently, this study attempts to address these gaps by asking two research questions:

- How does virtual reality contribute to enhancing destination image for families?

- How does virtual reality contribute to reducing perceived destination choice risk for family travel planning? 


\subsection{Methodology}

The research was approached from an interpretivist paradigm. In this study, it allowed a deeper understanding into the "how's" and "why's" of virtual reality's effects from the participants' standpoints. The 'how and why' was particularly important in this study as it was an exploratory one looking to construct theories, which interpretivism is naturally suited to (Jebreen, 2012). Given that the aim of this study was to gain a deeper understanding into how and why virtual reality influences families' destination choice and travel planning decisionmaking processes, a qualitative approach was deemed the best fitting method. The qualitative semi-structured interview approach is also utilised by Pantelidis et al. (2018) in their study on on-site VR experience in rural tourism. In recent studies on destination image, the qualitative approach is similarly deemed most suitable by Ryan and Cave (2016). Additionally, using a qualitative method allows better understanding of participant interactions and group decisionmaking processes in travel planning.

\subsection{Respondents' Criteria}

Considering the research questions of VR's contribution to family travel planning, the population of choice was families who travel. Schänzel and Smith (2014) have posited that, "focussing research in family tourism on individual members, as is the predominant case, desocialises the family group and lacks a triadic or familiar perspectives that is inclusive of group dynamics and sociality" (p.138). Heeding their call, the sampling approach for this study was purposive, and respondents were qualified as families who travel where one or more persons in the family, usually children, do not contribute financially to the travelling expenses. Ethics clearance was gained for interviewing the families as a whole. Snowball sampling was particularly suitable as families who travel generally know other families who travel (Patton, 2002; Therkelsen, 2010). Due to this, as well as the interviewer's location, sampling was 
geographically limited to Brisbane, Australia. At the point of saturation (May 2017), 48 participants (12 families - 12 father, 12 mothers, 15 girls, and 9 boys) totalling 12 interviews were completed. Using a similar whole family method, Schänzel (2012) achieved saturation with 10 families.

\subsection{Data Collection}

In-depth semi-structured interviews were utilised, with the family as a whole in a group interview. The interviews took place after all respondents, including children, had experienced the VR experiences. Unlike focus groups, where group interaction is the method with moderators to minimize group dynamics from silencing voices (Kitzinger, 1995); group interviews focus on the researcher asking probing questions and driving the interview. It is suited to situations where realities are defined in a group context, like the modern-day family (Frey \& Fontana, 1991); which has shown a significant trend towards joint decision making (Litvin et al., 2004). With emphasis on the method, Thomson et al. (2007) found that children had direct influence over purchasing decisions and were a significant inclusion in the joint decision making process. Therkelsen (2010) similarly advocated utilising family group interviews and also found children played a significant role in the joint decision-making process. In a similar approach to this study, Schänzel (2012) combined whole-family group interviews with interpretivism to explore internal group dynamics during family holidays. She emphasized the importance of including the whole family in contributing toward more comprehensive understandings of contemporary family holiday experiences. Giving children a voice in the research ensured authenticity in understanding how families are influenced by VR in planning their vacations.

Prior to the interviews, one at a time, all respondents experienced two VR experiences to give a general idea as well as a tangible experience of how it may influence their travel planning 
behaviour. This started with the 'Australia in 360' application by Tourism Australia. In this first experience, each participant spent two to three minutes familiarising themselves with the interface and equipment then virtually experienced Sydney, the Great Ocean Road, or Gold Coast. Each VR experience in the Tourism Australia application was about one minute in length. In the second virtual experience, the application used was 'The Wild Within' experience, by Tourism British Columbia. This experience was longer at five minutes. Respondents experienced a virtual tour of the British Columbia backcountry in Canada. The equipment used was a Samsung Galaxy S7 Edge connected to the Samsung Gear VR headset. The experiences and interviews took place in the respondents' own homes.

Importantly, the first author who undertook the main data collection is single, male scholar with no children in his late 20s. As Hay (2017) noted, male researchers face particular challenges because of their gender when dealing with family studies involving children; in the case of this study, primarily child protection (Khoo-Lattimore, 2015). This explains the reason that there are only nuclear families involved in the study. Potential participants, particularly single-mother family units, did not feel comfortable letting the author into their homes for extended periods required for data collection. In fact, even with snowball-sampling, where the author was recommended or 'backed' by one family to another, establishing the trust required to allow a relatively young male scholar into the family home for several hours was very difficult to establish. Timing was also very challenging, with weeknights being too late for the children and parents understandably not wanting to commit a block of time during the weekends. This was particularly compounded when the data collection process did not offer any rewards for participation. Being a single, male scholar may also have limited the quality of data collected because he could not identify with the issues his adult respondents were expressing; or have the necessary skills to engage and interview children. Khoo-Lattimore (2015) alluded to this methodological concern and future scholars should give this due 
deliberation.

\subsection{Data Analysis}

Thematic analysis was deemed the most appropriate technique to unpack and analyse data from the interviews. It is defined as "a method for identifying, analysing and reporting patterns and themes within the data" (Braun \& Clarke, 2006, p. 79). In following Braun and Clarke (2006)'s phases of thematic analysis, the process started with transcription, followed by reading and rereading and noting down initial thoughts, familiarizing with the data. Coding then followed in a systematic fashion across the entire data set before potential themes were formed. The coding was done manually in Microsoft Excel and was based on criteria for classification developed by Echtner and Ritchie (1993) and recently used by del Bosque and Martín (2008) and Kladou and Mavragani (2015) in their analytical methods (Figure 1).

[Figure 1 near here]

The themes were then checked in relation to the data sets and a thematic map was generated. The final two phases were moving into further defining and naming the themes before producing a report, the final opportunity for analysis, relating back to the literature review and research questions. Thematic analysis allows flexibility, and as a tool it provides rich and detailed, yet complex account of the data (Braun \& Clarke, 2006). Pairing in-depth interviews with thematic analysis has been used in similar research. Mura, Tavakoli, and Pahlevan Sharif (2016) used the approach in exploring authenticity in virtual worlds and tom Dieck and Jung (2015) used the approach in theoretical modelling of augmented reality acceptance. Like this study, both were early stage research attempting to explore the potential influence of new technology in tourism, where existing literature was limited.

In the specific context of this study, consideration must be given to the trustworthiness of the respondents' statements. Attention was paid to detecting response biases such as if parents 
were refraining from revealing disagreements with the researcher or if children were exaggerating only to get the researcher's or their parents' attention. After the first stage of coding was completed, a second coder went through the data to improve reliability. Additionally, resultant themes and codes were discussed in-depth with the first two authors. 


\subsection{Findings and Discussion}

\subsection{Respondents}

Table 1 summarises the respondent profiles of the 48 participants that were included in the analysis. All 12 families were residents of the greater Brisbane area where the interviews were held in the families' homes. The youngest parent was 37, with the oldest being 64 . For the children, the youngest participant was 3 years old, and the oldest was 24 . The three participants aged five years old and younger took part in experiencing parts of the VR demonstration with the help of their parents. However, apart from several yes or no answers regarding what they saw or how they felt, they did not contribute to the group interviews. Although it was not a requirement, the sample was made up of 12 nuclear families (between one and three children per family). They also ranged from middle class to upper middle class and due to the snowballing technique, there were perhaps more postgraduate and $\mathrm{PhD}$ graduates than reflected in the general population. Additionally, due to absence of single-parent or blended families, the sample was not representative of the diversity in Australian families. However, whilst all 12 families were residents of Brisbane, their ethnicities and nationalities were varied, ranging from Australians, to Malaysians, Jordanians, Indonesians, Taiwanese, Indians, and Finnish. [Table 1 near here]

\subsection{Virtual Reality's Influence on Destination Image.}

The first research question was to ascertain how does virtual reality contribute to enhancing destination image for families? Within the theme of destination image, comments were classified according to a specific destination image component (cognitive or affective), as espoused by the literature. Comments describing infrastructure, atmosphere, or socioeconomic/natural/cultural environment were placed in the cognitive theme. Comments describing how participants feel about the destination were placed in the affective theme. 


\subsubsection{Virtual Reality's Influence on Cognitive Components}

All participants found the VR experience provided richer information when compared to traditional media (videos and pictures). Within the theme of VR establishing stronger cognitive components toward forming more vivid images of the destination, participants found VR provided more information, understanding, and awareness of the location as a potential vacation destination. They also felt VR contributed toward forming expectations about the destination experience, as well as potentially aiding preparation for the future trip. These outcomes were often attributed to the sense of immersion that VR provided. The 360' view providing a 'better sense of the destination' was also a notion that was commonly referenced.

Table 2. Virtual Reality's Influence on Destination Awareness and Understanding.

\begin{tabular}{|c|c|}
\hline $\begin{array}{l}\text { Mother, 45, } \\
\text { Family } 1\end{array}$ & $\begin{array}{l}\text { When making a decision I think it's helpful. Because it helps } \\
\text { me see the } 360 \text { ' of the whole scenery. That would help me to } \\
\text { have a better understanding of what things I could expect. }\end{array}$ \\
\hline $\begin{array}{l}\text { Father, 39, } \\
\text { Family } 2\end{array}$ & $\begin{array}{l}\text { It's useful, to be aware of what's available. For places like } \\
\text { Canada, particularly in places where it's less familiar. It } \\
\text { heightens awareness. }\end{array}$ \\
\hline $\begin{array}{l}\text { Mother, 44, } \\
\text { Family } 12\end{array}$ & $\begin{array}{l}\text { I was able to sort of go 'oh, there's something on Canada'. I } \\
\text { think that is probably far more enticing than watching } \\
\text { something on the TV or anything like youtube. }\end{array}$ \\
\hline Family 6 & $\begin{array}{l}\text { Son, 14: It informs you a lot more and give you more insight. } \\
\text { Mother, 49: Absolutely. On VR it would give us a lot more } \\
\text { insight into the accommodation cause you can actually see } \\
\text { 'does that actually suit our family and our set up'. I think } \\
\text { we'd definitely use it more... }\end{array}$ \\
\hline
\end{tabular}


Father, 51: Especially for planning our trips. For example, we're planning a few days in Tokyo. Imagine we sat here and say let's look at... a certain area. If you could VR some of the snippets of things you could do, to me it would be beneficial.

The cognitive component of destination image is connected to awareness and refers to what people think they know about a destination (del Bosque \& Martín, 2008; Echtner \& Ritchie, 1993; Kladou \& Mavragani, 2015). As seen in Table 2, participants felt that VR contributed to higher awareness and the $360^{\prime}$ views aided them in better understanding the destination, confirming VR's contribution toward the cognitive component by providing much more information than traditional media.

Table 3. Virtual Reality's Influence on Presence.

\begin{tabular}{|c|c|}
\hline Family 3 & $\begin{array}{l}\text { Daughter, 14: I haven't done anything like it, and it felt like I } \\
\text { was there... when I was up high, I felt like I was going to fall } \\
\text { over. } \\
\text { Mother, 47: Yeah, you feel like you're there. When it went up, } \\
\text { and you could just see the whole view. You could feel the } \\
\text { atmosphere... I could be there on that deck chair, with the fire. } \\
\text { I want to go there! It was just beautiful, so beautiful and the } \\
\text { mist and the mountains, and the fire. }\end{array}$ \\
\hline $\begin{array}{l}\text { Father, 63, } \\
\text { Family } 5\end{array}$ & $\begin{array}{l}\text { You really do feel like you were there. It's registered more } \\
\text { deeply with me than just a straight } 2 D \text { clip. Your brain does } \\
\text { fool yourself into believing you're there. It's almost as though } \\
\text { you've been transported there. It does immerse you. It's stuck } \\
\text { in my memory. I really do want to go there. }\end{array}$ \\
\hline
\end{tabular}




\begin{tabular}{l|l}
\hline Daughter, 10, & Ifelt like I was part of it. Feels like you're there. I could also \\
Family 10 & feel a bit more attraction because you're part of the tour.
\end{tabular}

The referrals in Table 3 to the feeling of 'being there' or 'it felt real' is attributed to the concept of presence, which is defined as "the sense of being in an environment" (Steuer, 1992, p. 75). This supports Mikropoulos and Strouboulis (2004)'s findings that the environmental richness attributed to VR resulted in a higher degree of presence, which is correlated to higher levels of cognitive performance. The notion that presence and 'the feeling of being there' contributes to cognitive components also support Wan et al. (2007) findings that virtual experiences provided more effective advertising compared to brochures due to the richness of the information. In their studies on destination image, both del Bosque and Martín (2008) and Kladou and Mavragani (2015) classified criteria for cognitive components from comments of tourists who had travelled to the destination and were then describing or reviewing them. Participants in this study had only experienced the destination virtually without actually having been there. Yet, as evidenced in Table 4, they were still able to describe the infrastructure, atmosphere, and environment according to the same criteria.

Table 4. Participant Describing Cognitive Components of the VR Experience.

\begin{tabular}{l|l} 
Daughter, 24, & $\begin{array}{l}\text { I think that VR gives you way better understanding of the } \\
\text { Family } 9\end{array}$ \\
Yestination cause you're there and you feel like you've seen it. \\
travel experience. That awareness is so much greater because \\
it's the experience, not just a photo.
\end{tabular}

Similarly, the following comment in Table 5 particularly matched the description of a vicarious experience by Zhai (1998), who described it as the experience of being in one place while located physically in another place during one's normal state of consciousness. 
Table 5. Participant Describing Vicarious Experience.

\begin{tabular}{l|l}
\hline Mother, 40, Family & For a short moment I went to Canada, and I was there. \\
$\mathbf{4}$ & \\
\hline
\end{tabular}

Conceptual papers posited that VR's ability to visualise spatial environments and create a vicarious experience would be its biggest strength for tourism (Guttentag, 2010; Zhai, 1998). The findings here empirically support that suggestion, showing that through the vicarious experience, tourists are able to form these strong cognitive images. If the ultimate goal for webbased destination marketing is to provide travel information to tourists via a vicarious experience of the destination to persuade them to visit (Huang et al., 2016), these findings highlight the value that VR will provide to DMOs.

\subsubsection{Virtual Reality's Influence on Affective Components}

Comments in the following section consist of emotion arousal and peoples' feelings about the destination. Based on the literature and criteria from Figure 1, these were categorised as affective components. Researchers agree on the central importance of the cognitive aspect as cognitive components also contribute to emotions, or affective components (del Bosque \& Martín, 2008; Kladou \& Mavragani, 2015; Kock et al., 2016). The VR experience was able to evoke emotions such as nostalgia, peace, love, and amazement which are classified as part of the affective component of destination image.

Table 6. Participants Describing Virtual Reality's Influence on their Emotions.

\begin{tabular}{l|l}
\hline Daughter, 12, & The boat was moving but it was very empty, very still, and I \\
Family 3 & felt very peaceful. I liked that.
\end{tabular}


Mother, 39,

Family 11
It gave the sense of quietness. Yeah, it's peaceful when the boat is moving. The VR reminded me of the fjords in Oslo, the beautiful quiet.

In their study, Kladou and Mavragani (2015) labelled expressions like 'wow', 'amazing', and 'love' as some of the stronger affective components. Again, their results were based on reviews by tourists describing their holidays. The fact that some of these appeared in comments from participants (Table 6) in this study suggests that the virtual experience is immersive enough to generate the same affective experiences. The results also further support existing literature on destination image that emphasizes the central importance of cognitive components contributing to affective components. Through providing a richer sensory experience, participants exhibited positive feelings and emotions toward the destination, with a few expressing the intention to visit, which suggests the activation of the conative component of destination image (Table 7).

Table 7. Virtual Reality's Influence on Affect and Intention to Visit.

\section{Family 6}

Mother, 49: The Canadian one I loved because it transformed me to a placed that I hadn't really been and something I hadn't seen. I really would love to go and see that.

Son, 10: Absolutely, yeah. You felt like you were in the boat with them.

Son, 14: You felt like you were part of the tour. Yeah, I mean it'd be cool to visit, like, that place.

Father, 51: I don't think I have a say. Looks like we're going to Canada soon. [laugh] I love that idea of the log cabin... with the fireplace and all four of us sitting around in chairs. 
That really looked nice. [mom] would like that. Have the seals

just floating up underneath.

\begin{tabular}{l|l} 
Mother, 40, & $\begin{array}{l}\text { That reminded me of my home country and my younghood and } \\
\text { Family } 4\end{array}$ \\
\begin{tabular}{l|l} 
Mother, 44, \\
Family 12
\end{tabular} & $\begin{array}{l}\text { It mas really kind of nostalgic. I would like to go there. } \\
\text { the resort at the end. I just loved the look of it. I just went } \\
\text { 'wow! That's just amazing.' I loved that it had mountains } \\
\text { surrounding it, this eco style resort and everyone was sort of } \\
\text { sitting out on that big lake deck. Fire in the middle. Got a real } \\
\text { feel for the location, I'd definitely go there. }\end{array}$
\end{tabular}

Finding that the VR experience led to several participants intending to visit the destination aligns with results in previous research on 3D reconstructions of tourism sites in virtual worlds (Huang et al., 2016; Pantano \& Servidio, 2011) and extends empirical evidence to include 360' VR. The findings also support existing research suggesting that providing potential consumers vivid information with facets of enjoyment and interactivity is vital to evoke imagery and vicarious experiences of the featured destination; leading to stronger emotional responses and consequently higher levels of product interest (Gammack \& Hodkinson, 2003; Goossens, 2000; Koufaris, 2002; Walters, Sparks, \& Herington, 2012). The interaction within Family 6 in Table 7 highlights the process of the cognitive, affective, and conative components of destination image being activated by the VR experience; the resulting family dynamics possibly amplifying the effects. These findings suggest the value VR, advancing the destination image aspects of traditional media, in being an addition to the marketing mixes of DMOs.

\subsection{Virtual Reality's Influence on Perceived Destination Choice Risk}

VR reducing perceived destination choice risk was another theme that emerged from the 
findings. Participants commented that the rich information they received from the VR experience aided them in determining if the destination of choice would match their expectations. Notions of reduction in perceived financial risk were found in participants' comments.

Table 8. Virtual Reality's Influence on Perceived Performance Risk.

\begin{tabular}{|c|c|}
\hline Father, 39, & $\begin{array}{l}\text { Based on that experience, it might help people be more } \\
\text { discerning about where they go and stop disappointment } \\
\text { going to places they didn't expect were going to be a certain } \\
\text { way. }\end{array}$ \\
\hline $\begin{array}{l}\text { Father, 43, } \\
\text { Family } 3\end{array}$ & $\begin{array}{l}\text { We've been to a few places where the promoter in New } \\
\text { Zealand told us 'it'll fit } 7 \text { people yes'. You get there and there } \\
\text { was like } 3 \text { bedrooms, and } 2 \text { doubles. We all have to share } 1 \\
\text { bed. But if we had the accommodation virtual reality. What's } \\
\text { the accommodation like, what's the actual room. We want to } \\
\text { see it. And you can go 'oh no, we're not staying in that } \\
\text { because we have to have } 1 \text { bed each'. }\end{array}$ \\
\hline
\end{tabular}

The comments in Table 8 highlight the benefits of being able to vicariously experience or 'preview' a destination or attraction, reflecting on if it aligns with their expectations and motivations. When the cognitive information was sufficient to give a good sense of the destination, participants felt like they could judge for themselves, based on their own interests and motivations, if they would be satisfied by travelling to the destination. Performance risk is defined as "the product not performing as expected and advertised" (Featherman \& Pavlou, 2003, p. 455). The findings indicate that using VR, participants felt they could reduce perceived performance risk. This aspect was particularly prevalent in families that considered themselves culturally different from their peers as seen in Table 9. 
Table 9. Virtual Reality's Influence on Perceived destination choice risk for Culturally Different Families.

\section{Family 8 (Jordanian family living in Brisbane)}

\begin{tabular}{|c|c|}
\hline Father, 39 & $\begin{array}{l}\text { With the VR, my judgement becomes a priority. I can see the } \\
\text { colours are not as the people say it is. Or the streets are dirty } \\
\text { or the people are not as friendly, they look gloomy. I would } \\
\text { have an experience before I go there. 'Yes, I like what I'm } \\
\text { seeing'. Because we're from a different culture. What we think } \\
\text { is 'wow' maybe someone else will just think it's ok. }\end{array}$ \\
\hline Mother, 36 & $\begin{array}{l}\text { The glow worms in Mt Tambourine. Everyone was saying } \\
\text { watch the worms. It was a disappointment. Because we didn't } \\
\text { know what's inside. We had to pay a good amount of money } \\
\text { and go there and stay in a small built tunnel, stay there and } \\
\text { listen for the signs of that for } 15 \text { minutes. The kids wanted to } \\
\text { leave. They were annoying the people around us. Whereas if I } \\
\text { saw the VR about that, it will be according to my own } \\
\text { judgement and what I think is good or not. }\end{array}$ \\
\hline
\end{tabular}

In this instance, the family felt that VR would give them a clearer picture of what they could expect from the destination, an aspect that remains a challenge with traditional media such as video and pictures, or word-of-mouth from their peers. The increased level of interactivity from VR giving them an increased level of control to make judgements based on their own family's set of needs or expectations of a good attraction.

It was also relatively unsurprising to find that with the families, safety was a central concern. Especially families with younger children, the VR experience allowed them to better judge the perceived safety of the destination as seen in Table 10. 
Table 10. Virtual Reality's Influence on Perceived Safety Risk.

\section{Family 2 (Children aged 9 and 3)}

\begin{tabular}{|c|c|}
\hline Father, 39 & $\begin{array}{l}\text { Particularly when you're travelling with kids this allows you to } \\
\text { be aware if the place is kid friendly. Like she [daughter] said, } \\
\text { she doesn't want to go to great ocean road cause she might } \\
\text { fall off the cliff. It gives you more of that realistic experience. } \\
\text { See the potential risk and safety issues. }\end{array}$ \\
\hline Mother, 37 & $\begin{array}{l}\text { Thinking about the seal part. I probably won't do that because } \\
\text { the boat is so small and my kids are little. So it's risky. I can } \\
\text { see the reality and say this isn't very suitable for me. And also, } \\
\text { the last house, it's actually quite dangerous for them, cause } \\
\text { there's no barrier. I won't go because I see more things there. }\end{array}$ \\
\hline
\end{tabular}

The literature review suggests that in tourism, VR can viably be positioned as a risk reduction tool due to the ability to vicariously experience aspects the destination before getting there. In families, because children do not contribute to the financial expenses of travel, the perceived risk in planning the destination increases due to the bigger financial outlay (Featherman \& Pavlou, 2003). Therefore, justification for focusing on families was that VR's impact on the family travel planning process will be larger when compared to other segments due to the reduction in perceived financial risk. Reduction of perceived financial risk as a theme was prevalent in the comments as seen in Table 11.

Table 11. Virtual Reality's Influence on Perceived Financial Risk.

\begin{tabular}{l|l} 
Father, 51, & $\begin{array}{l}\text { We're thinking of going to Japan later this year. We 've never } \\
\text { Family } 6\end{array}$ \\
been to Japan. If we could do a VR and have a look at some \\
options. Absolutely, I'd do it in a heartbeat. Big investment on
\end{tabular}




\begin{tabular}{|c|c|}
\hline & $\begin{array}{l}\text { a holiday for us, it makes sense for us to use VR and say, well } \\
\text { what's the one thing for us to do here. }\end{array}$ \\
\hline $\begin{array}{l}\text { Daughter, 24, } \\
\text { Family } 5\end{array}$ & $\begin{array}{l}\text { You don't want to waste money on something that wasn't } \\
\text { enjoyable. It is financial. I don't book hotels without photos, } \\
\text { so VR would be a next step in that. }\end{array}$ \\
\hline $\begin{array}{l}\text { Mother, } 45 \text {, } \\
\text { Family } 1\end{array}$ & $\begin{array}{l}\text { I find it particularly useful; it helps me to make a decision on } \\
\text { experience tours that cost a lot of money. I think I would like } \\
\text { to have a preview for that purpose. }\end{array}$ \\
\hline $\begin{array}{l}\text { Mother, 52, } \\
\text { Family } 9\end{array}$ & $\begin{array}{l}\text { If I could walk into a travel agent... and tell them } 2 \text { or } 3 \\
\text { places I'm thinking of going and I could look at the VR for } \\
\text { each place, that would be a big help. It is a lot of money when } \\
\text { you're booking a holiday and if you're not happy with where } \\
\text { you book, it's disappointing. }\end{array}$ \\
\hline
\end{tabular}

Through the participant's comments, it is evident that VR influences the families' destination selection by reduction of perceived destination choice risk. Participants attributed the reduction of perceived destination choice risk to having a higher level of product knowledge through being immersed in the virtual environment. By reducing the perceived risk in performance, safety, and financially, they felt more confident and certain in their decision-making. Additionally, participants' comments seen in Table 8 and 9 suggest that using VR to preview their accommodation and attraction would have reduced or avoided the conflict and stress that arose in past family holidays due to misinformation or misunderstanding. This highlights the value of VR particularly for family travel, where inadequate or unsuitable attractions or facilities can lead to family holidays, especially those travelling with younger children, increasing instead of reducing stress and conflict (Backer \& Schänzel, 2015). This finding supports studies by Cheong (1995), Berger et al. (2007), and Guttentag (2010) positing that 
VR's ability to visualise spatial environments to provide rich information to tourists in the planning stage, then being able to compare different destination previews; would help immensely in consumers making informed decisions.

In positioning VR as a risk reduction tool for families, the findings also support existing research showing that the decision-making process in families is more complex when compared to the solo traveller and destination marketers can gain from positioning themselves even more specifically within the segment (Litvin et al., 2004; Schänzel \& Yeoman, 2015b; Therkelsen, 2010; Thomson et al., 2007). All parents felt like they needed more resources and risk reduction especially when travelling with their families. The findings and discussion on VR's influence on perceived destination choice risk can be summarised as a thematic map of the findings and relationships with respect to the decision-making processes presented as Figure 2.

[Figure 2 near here] 


\subsection{Conclusion}

\subsection{Contributions of the Study}

\subsubsection{Theoretical Contributions}

This study contributes to the existing VR literature in tourism with a theoretical framework of VR's influence on family travel planning via destination image and perceived destination choice risk presented here as Figure 3. By empirically researching 360' VR, this study expands previous research in a field that has primarily focused on virtual worlds (Huang et al., 2016; Huang, Backman, Backman, \& Moore, 2013; Singh \& Lee, 2009; tom Dieck \& Jung, 2015). This is an important distinction to make. Whilst virtual worlds are considered virtual reality, users still experience the environments through a computer monitor or television. The form of VR explored in this study completely immerses the user with 360 ' field of views through headmounted displays. As reported in the findings, this is a key factor that results in the feeling of presence.

Consistent with the literature, this study also found that affective components were influenced by cognitive information participants developed from VR. The cognitive component, alongside participants' enjoyment of the VR experience, influenced participants' feelings toward the destination, therefore contributing to the affective component. Based on previous research, destination image consists of both cognitive and affective components, therefore the results show that VR contributed to a clearer destination image via better understanding and awareness of the destination.

[Figure 3 near here]

Additionally, the increased cognitive components led to families being able to reduce perceived risk of destinations. Reducing perceived destination choice risk consisted of reducing 
performance, safety, and financial risk as participants felt they could better judge the destinations and what they could expect prior to making a transaction and travelling to the destination. Where findings were consistent with literature suggesting the increased information from VR experiences would contribute to reduction of perceived financial and performance risk for families (Featherman \& Pavlou, 2003; Therkelsen, 2010), a significant contribution from the findings is the importance of how the VR experience allowed participants to gauge the safety risk of the destination. This was particularly evident in families with younger children and influenced their intention to visit the destination. Through the VR experience, participants could better evaluate, based on their destination image and perceived destination choice risk, if they intended to visit the destination.

\subsubsection{Practical Contributions}

The findings from this study show that, at least for families, VR is a progression toward consumers receiving more tangible information. Destination marketers should focus on portraying attractions in VR based on their targeted market's needs, identifying information that potential tourists perceive as useful. For instance, several families in this study were able to decide against going to the destination viewed in the British Columbia experience due to safety and practicality concerns. Destination marketers and content developers intending to adapt VR to target the family market segment should create content that relates to families. One option would be to produce experiences from the perspective of an entire family, instead of the individual-focused experiences that are available currently.

In placing VR within the wider array of marketing tools, the findings also show the value that VR could bring in addition to the traditional marketing mix of videos, pictures, and brochures. Features from VR such as the levels of immersion and presence bring unprecedented advances to traditional media and the findings from this study show the impacts on potential travellers' 
enjoyment, understanding, and awareness of the destination, leading to intention to visit the destination. For destination marketers, these effects could be beneficial. Especially in a postCOVID travel environment where perceived destination choice risk, particularly for families, could be increased - and with it, a demand for richer information in making decisions about family holidays. Future studies doing direct comparisons of VR to traditional marketing media tools would provide important and interesting insights for organisations considering the value of adding of VR to their marketing mixes.

\subsection{Limitations}

While this study provides insights into VR's utility as a destination selection tool for families, it has several limitations, many of which provide a foundation for future research in the context of VR in tourism. The first limitation is generalizability. This study explored only the application of the Samsung Gear VR and virtual experiences from Tourism Australia and Tourism British Columbia specifically. Therefore, the findings may not be generalizable to other destination experiences or tiers of VR equipment. Specifically, regarding the equipment, user experience will possibly differ at other grades and price points. Future studies could possibly explore the effect of using a wide range of VR equipment, from the entry-level Google Cardboard to top-tier options like the Oculus Rift; as well as exploring different destination VR experiences once they become available. Different forms of VR dissemination could also be investigated, exploring the potential differences between platforms - for instance, if or how the influence of VR differs when hosted on official websites compared to social media. Moreover, this study collected data primarily from families based in the Brisbane area. Due to the snowballing technique, many participants were connected to academia as well as being middle to upper middle class, which may not be representative of the general population. Additionally, due to the qualitative and exploratory nature of this study, the number of 
participants were relatively small. In obtaining a more generalizable result, future studies could explore other market segments, such as backpackers or female leisure travellers as well as a more diversified demographic. Where this study focused more on VR as a tool for family tourism, future researchers could focus primarily on the family group dynamics and behaviour when using VR in a tourism context; particularly when VR advances to a point of allowing multi-user experiences. Finally, this study only focused on a particular subset of possible determinants to user experience and usage behaviour in using VR for travel planning. Future studies could explore other facets and predictors that possibly influence usage behaviour and user experience in the context of using VR for travel planning. More quantitative or mixed methods, such as pre and post assessments of VR usage, in an experiment setting, and well as possible use of psychophysiological measures could provide important insights in future research. Despite the limitations, this is the first study on 360 ' VR in family tourism, identifying strengths and issues for future research to build upon.

Acknowledgements

This work was supported by the Griffith Institute for Tourism. 


\section{REFERENCES}

Agapito, D., Oom do Valle, P., \& da Costa Mendes, J. (2013). The Cognitive-AffectiveConative Model of Destination Image: A Confirmatory Analysis. Journal of Travel \& Tourism Marketing, 30(5), 471-481. doi: 10.1080/10548408.2013.803393.

Anderson, N. H. (1981). Information integration theory: New York: Academic Press.

Backer, E., \& Schänzel, H. (2015). Family Holidays-Vacation or Obli-cation? Tourism Recreation Research, 38(2), 159-173. doi: 10.1080/02508281.2013.11081742.

Baloglu, S., \& McCleary, K. W. (1999). A model of destination image formation. Annals of Tourism Research, 26(4), 868-897. doi: 10.1016/s0160-7383(99)00030-4.

Beck, J., Rainoldi, M., \& Egger, R. (2019). Virtual reality in tourism: a state-of-the-art review. Tourism Review, 74(3), 586-612. doi: 10.1108/tr-03-2017-0049.

Berger, H., Dittenbach, M., Merkl, D., Bogdanovych, A., Simoff, S., \& Sierra, C. (2007). Opening new dimensions for e-Tourism. Virtual Reality, 11(2), 75-87. doi: 10.1007/s10055-006-0057-z.

Berger, I. E., \& Mitchell, A. A. (1989). The effect of advertising on attitude accessibility, attitude confidence, and the attitude-behavior relationship. Journal of Consumer Research, 16(3), 269-279.

Braun, V., \& Clarke, V. (2006). Using thematic analysis in psychology. Qualitative Research in Psychology, 3(2), 77-101. doi: 10.1191/1478088706qp063oa.

Bronner, F., \& de Hoog, R. (2008). Agreement and disagreement in family vacation decisionmaking. Tourism Management, 29(5), 967-979. doi: 10.1016/j.tourman.2007.12.001.

Burgess, L., Parish, B., \& Alcock, C. (2011). To what extent are regional tourism organisations (RTOs) in Australia leveraging the benefits of web technology for destination marketing and eCommerce? Electronic Commerce Research, 11(3), 341355. doi: 10.1007/s10660-011-9077-1.

Cheong, R. (1995). The virtual threat to travel and tourism. Tourism Management, 16(6), 417-422. doi: 10.1016/0261-5177(95)00049-T.

Chew, E. Y. T., \& Jahari, S. A. (2014). Destination image as a mediator between perceived risks and revisit intention: A case of post-disaster Japan. Tourism Management, 40, 382-393. doi: 10.1016/j.tourman.2013.07.008.

Cho, Y.-H., Wang, Y., \& Fesenmaier, D. R. (2002). Searching for Experiences. Journal of Travel \& Tourism Marketing, 12(4), 1-17. doi: 10.1300/J073v12n04_01.

Choi, J., Ok, C., \& Choi, S. (2016). Outcomes of Destination Marketing Organization Website Navigation: The Role of Telepresence. Journal of Travel \& Tourism Marketing, 33(1), 46-62. doi: 10.1080/10548408.2015.1024913.

Chung, N., Lee, H., Lee, S. J., \& Koo, C. (2015). The influence of tourism website on tourists' behavior to determine destination selection: A case study of creative economy in Korea. Technological Forecasting and Social Change, 96, 130-143. doi: 10.1016/j.techfore.2015.03.004.

Cranford, M. (1996). The social trajectory of virtual reality: Substantive ethics in a world without constraints. Technology in Society, 18(1), 79-92. doi: 10.1016/0160791x(95)00023-k.

Darley, W. K., \& Lim, J.-S. (1986). Family decision making in leisure-time activities: An exploratory investigation of the impact of locus of control, child age influence factor and parental type on perceived child influence. ACR North American Advances. 
Deale, C. S. (2013). Incorporating Second Life into online hospitality and tourism education: A case study. Journal of Hospitality, Leisure, Sport \& Tourism Education, 13, 154160. doi: 10.1016/j.jhlste.2013.09.002.

del Bosque, I. R., \& Martín, H. S. (2008). Tourist satisfaction a cognitive-affective model. Annals of Tourism Research, 35(2), 551-573. doi: 10.1016/j.annals.2008.02.006.

Destination BC. (2014). Destination BC Creates The Wild Within VR Experience. Retrieved from http://www.destinationbc.ca/news/local/destination-bc-creates-the-wild-withinvr-experien.aspx

Disztinger, P., Schlögl, S., \& Groth, A. (2017). Technology Acceptance of Virtual Reality for Travel Planning Information and Communication Technologies in Tourism 2017 (pp. 255-268).

Dueholm, J., \& Smed, K. M. (2014). Heritage authenticities - a case study of authenticity perceptions at a Danish heritage site. Journal of Heritage Tourism, 9(4), 285-298. doi: 10.1080/1743873x.2014.905582.

Durl, J., Dietrich, T., Pang, B., Potter, L.-E., \& Carter, L. (2017). Utilising virtual reality in alcohol studies: A systematic review. Health Education Journal, 1-14. doi: 10.1177/0017896917743534.

Echtner, C. M., \& Ritchie, J. R. B. (1993). The Measurement of Destination Image: An Empirical Assessment. Journal of Travel Research, 31(4), 3-13. doi: $10.1177 / 004728759303100402$.

Featherman, M. S., \& Pavlou, P. A. (2003). Predicting e-services adoption: a perceived risk facets perspective. International Journal of Human-Computer Studies, 59(4), 451474. doi: 10.1016/s1071-5819(03)00111-3.

Filiatrault, P., \& Ritchie, J. R. B. (1980). Joint Purchasing Decisions: A Comparison of Influence Structure in Family and Couple Decision-Making Units. Journal of Consumer Research, 7(2), 131-140. doi: 10.1086/208802.

Flavián, C., Ibáñez-Sánchez, S., \& Orús, C. (2019a). The impact of virtual, augmented and mixed reality technologies on the customer experience. Journal of Business Research, 100, 547-560. doi: 10.1016/j.jbusres.2018.10.050.

Flavián, C., Ibáñez-Sánchez, S., \& Orús, C. (2019b). Integrating virtual reality devices into the body: effects of technological embodiment on customer engagement and behavioral intentions toward the destination. Journal of Travel \& Tourism Marketing, 36(7), 847-863. doi: 10.1080/10548408.2019.1618781.

Foxman, E. R., Tansuhaj, P. S., \& Ekstrom, K. M. (1989). Family Members' Perceptions of Adolescents' Influence in Family Decision Making. Journal of Consumer Research, 15(4), 482-491. doi: 10.1086/209187.

Frey, J. H., \& Fontana, A. (1991). The group interview in social research. The Social Science Journal, 28(2), 175-187. doi: 10.1016/0362-3319(91)90003-m.

Gallarza, M. G., Saura, I. G., \& García, H. C. (2002). Destination image. Annals of Tourism Research, 29(1), 56-78. doi: 10.1016/s0160-7383(01)00031-7.

Gammack, J., \& Hodkinson, C. (2003). Virtual reality, involvement and the consumer interface. Journal of End User Computing, 15(4), 78.

Gartner, W. C. (1994). Image Formation Process. Journal of Travel \& Tourism Marketing, 2(2-3), 191-216. doi: 10.1300/J073v02n02_12.

Goossens, C. (2000). Tourism Information And Pleasure Motivation. Annals of Tourism Research, 27(2), 301-321.

Gorini, A., Griez, E., Petrova, A., \& Riva, G. (2010). Assessment of the emotional responses produced by exposure to real food, virtual food and photographs of food in patients affected by eating disorders. Ann Gen Psychiatry, 9, 30. doi: 10.1186/1744-859X-930 . 
Govers, R., Go, F. M., \& Kumar, K. (2007). Virtual destination image a new measurement approach. Annals of Tourism Research, 34(4), 977-997. doi: 10.1016/j.annals.2007.06.001.

Gram, M. (2005). Family Holidays. A Qualitative Analysis of Family Holiday Experiences. Scandinavian Journal of Hospitality and Tourism, 5(1), 2-22. doi: 10.1080/15022250510014255.

Gretzel, U., Fesenmaier, D. R., Formica, S., \& O'Leary, J. T. (2006). Searching for the Future: Challenges Faced by Destination Marketing Organizations. Journal of Travel Research, 45(2), 116-126. doi: 10.1177/0047287506291598.

Gursoy, D., \& McCleary, K. W. (2004). An Integrative Model of Tourists' Information Search Behavior. Annals of Tourism Research, 31(2), 353-373. doi: 10.1016/j.annals.2003.12.004.

Guttentag, D. A. (2010). Virtual reality: Applications and implications for tourism. Tourism Management, 31(5), 637-651. doi: 10.1016/j.tourman.2009.07.003.

Han, H., Hwang, J., \& Woods, D. P. (2014). Choosing Virtual - Rather than Real - Leisure Activities: An Examination of the Decision-making Process in Screen-Golf Participants. Asia Pacific Journal of Tourism Research, 19(4), 428-450. doi: 10.1080/10941665.2013.764333.

Hay, B. (2017). Missing voices: Australian children's insights and perceptions of family holidays. Hospitality \& Society, 7(2), 133-155. doi: 10.1386/hosp.7.2.133_1.

Hjalager, A.-M. (2010). A review of innovation research in tourism. Tourism Management, 31(1), 1-12. doi: 10.1016/j.tourman.2009.08.012.

Hobson, J. S. P., \& Williams, A. P. (1995). Virtual reality: A new horizon for the tourism industry. Journal of Vacation Marketing, 1(2), 124-135. doi: 10.1177/135676679500100202.

Howard, D. R., \& Madrigal, R. (1990). Who makes the decision: The parent or the child? The perceived influence of parents and children on the purchase of recreation services. Journal of leisure research, 22(3), 244-258.

Huang, Y.-C., Backman, K. F., Backman, S. J., \& Chang, L. L. (2016). Exploring the Implications of Virtual Reality Technology in Tourism Marketing: An Integrated Research Framework. International Journal of Tourism Research, 18(2), 116-128. doi: $10.1002 /$ jtr.2038.

Huang, Y.-C., Backman, S. J., Backman, K. F., \& Moore, D. (2013). Exploring user acceptance of 3D virtual worlds in travel and tourism marketing. Tourism Management, 36, 490-501. doi: 10.1016/j.tourman.2012.09.009.

Huang, Y.-C., Backman, S. J., Chang, L.-L., Backman, K. F., \& McGuire, F. A. (2013). Experiencing student learning and tourism training in a 3D virtual world: An exploratory study. Journal of Hospitality, Leisure, Sport \& Tourism Education, 13, 190-201. doi: 10.1016/j.jhlste.2013.09.007.

Hyun, M. Y., \& O'Keefe, R. M. (2012). Virtual destination image: Testing a telepresence model. Journal of Business Research, 65(1), 29-35. doi: 10.1016/j.jbusres.2011.07.011.

Jebreen, I. (2012). Using Inductive Approach as Research Strategy in Requirements Engineering. International Journal of Computer and Information Technology, 1(2), 162-173.

Jenkins, R. L. (1978). Family Vacation Decision-Making. Journal of Travel Research, 16(4), 2-7. doi: 10.1177/004728757801600401.

Jung, T., tom Dieck, M. C., Moorhouse, N., \& tom Dieck, D. (2017). Tourists' experience of Virtual Reality applications 2017 IEEE International Conference on Consumer Electronics (ICCE) (pp. 208-210): IEEE. 
Kang, S. K., \& Hsu, C. H. C. (2005). Dyadic consensus on family vacation destination selection. Tourism Management, 26(4), 571-582. doi: 10.1016/j.tourman.2004.01.002.

Khoo-Lattimore, C. (2015). Kids on board: methodological challenges, concerns and clarifications when including young children's voices in tourism research. Current Issues in Tourism, 18(9), 845-858. doi: 10.1080/13683500.2015.1049129.

Khoo-Lattimore, C., del Chiappa, G., \& Yang, M. J. (2018). A family for the holidays: delineating the hospitality needs of European parents with young children. Young Consumers, 19(2), 159-171. doi: 10.1108/yc-08-2017-00730.

Khoo-Lattimore, C., Prayag, G., \& Cheah, B. L. (2015). Kids on Board: Exploring the Choice Process and Vacation Needs of Asian Parents With Young Children in Resort Hotels. Journal of Hospitality Marketing \& Management, 24(5), 511-531. doi: 10.1080/19368623.2014.914862.

Khoo-Lattimore, C., \& Yang, M. J. H. (2020). The constructions of family holidays in young middle-class Malaysian Chinese children. Journal of China Tourism Research, 16(1), 62-77.

Kitzinger, J. (1995). Qualitative Research: Introducing focus groups. Bmj, 311(7000), 299302. doi: 10.1136/bmj.311.7000.299.

Kladou, S., \& Mavragani, E. (2015). Assessing destination image: An online marketing approach and the case of TripAdvisor. Journal of Destination Marketing \& Management, 4(3), 187-193. doi: 10.1016/j.jdmm.2015.04.003.

Kock, F., Josiassen, A., \& Assaf, A. G. (2016). Advancing destination image: The destination content model. Annals of Tourism Research, 61, 28-44. doi: 10.1016/j.annals.2016.07.003.

Koufaris, M. (2002). Applying the Technology Acceptance Model and Flow Theory to Online Consumer Behavior. Information Systems Research, 13(2), 205-223. Retrieved from http://www.jstor.org.libraryproxy.griffith.edu.au/stable/23011056

Kozak, M., \& Duman, T. (2012). Family Members and Vacation Satisfaction: Proposal of a Conceptual Framework. International Journal of Tourism Research, 14(2), 192-204. doi: $10.1002 /$ jtr.847.

Lau, K. W., \& Lee, P. Y. (2012). The use of virtual reality for creating unusual environmental stimulation to motivate students to explore creative ideas. Interactive Learning Environments, 23(1), 3-18. doi: 10.1080/10494820.2012.745426.

Lepp, A., Gibson, H., \& Lane, C. (2011). Image and perceived risk: A study of Uganda and its official tourism website. Tourism Management, 32(3), 675-684. doi: 10.1016/j.tourman.2010.05.024.

Li, H., Daugherty, T., \& Biocca, F. (2002). Impact of 3-D Advertising on Product Knowledge, Brand Attitude, and Purchase Intention: The Mediating Role of Presence. Journal of Advertising, 31(3), 43-57.

Li, M., Xu, W., \& Chen, Y. (2020). Young children's vacation experience: Through the eyes of parents. Tourism Management Perspectives, 33. doi: 10.1016/j.tmp.2019.100586.

Lim, N. (2003). Consumers' perceived risk: sources versus consequences. Electronic Commerce Research and Applications, 2, 216-228. doi: 10.1016 / S15674223(03)00025-5.

Litvin, S. W., Xu, G., \& Kang, S. K. (2004). Spousal Vacation-Buying Decision Making Revisited across Time and Place. Journal of Travel Research, 43(2), 193-198. doi: $10.1177 / 0047287504268232$.

Liu, S.-q. (2005). A Theoretic Discussion of Tourism E-commerce 7th international conference on electronic commerce (pp. 1-5). Xi'an, China. 
MacKay, K. J., \& Fesenmaier, D. R. (1997). Pictorial element of destination in image formation. Annals of Tourism Research, 24(3), 537-565. doi: 10.1016/s01607383(97)00011-x.

Marasco, A., Buonincontri, P., van Niekerk, M., Orlowski, M., \& Okumus, F. (2018). Exploring the role of next-generation virtual technologies in destination marketing. Journal of Destination Marketing \& Management. doi: 10.1016/j.jdmm.2017.12.002.

Marchiori, E., Niforatos, E., \& Preto, L. (2018). Analysis of users' heart rate data and selfreported perceptions to understand effective virtual reality characteristics. Information Technology \& Tourism. doi: 10.1007/s40558-018-0104-0.

Mariani, M. M., Di Felice, M., \& Mura, M. (2016). Facebook as a destination marketing tool: Evidence from Italian regional Destination Management Organizations. Tourism Management, 54, 321-343. doi: 10.1016/j.tourman.2015.12.008.

Meehan, M., Razzaque, S., Insko, B., Whitton, M., \& Brooks, F. P., Jr. (2005). Review of four studies on the use of physiological reaction as a measure of presence in stressful virtual environments. Appl Psychophysiol Biofeedback, 30(3), 239-258. doi: 10.1007/s10484-005-6381-3.

Mikropoulos, T. A., \& Natsis, A. (2011). Educational virtual environments: A ten-year review of empirical research (1999-2009). Computers \& Education, 56(3), 769-780. doi: 10.1016/j.compedu.2010.10.020.

Mikropoulos, T. A., \& Strouboulis, V. (2004). Factors That Influence Presence in Educational Virtual Environments. CYBERPSYCHOLOGY \& BEHAVIOR, 7(5), $582-$ 591. doi: 10.1089/cpb.2004.7.582.

Molinillo, S., Liébana-Cabanillas, F., Anaya-Sánchez, R., \& Buhalis, D. (2018). DMO online platforms: Image and intention to visit. Tourism Management, 65, 116-130. doi: 10.1016/j.tourman.2017.09.021.

Mura, P., Tavakoli, R., \& Pahlevan Sharif, S. (2016). 'Authentic but not too much': exploring perceptions of authenticity of virtual tourism. Information Technology \& Tourism. doi: 10.1007/s40558-016-0059-y.

Nanda, D., Hu, C., \& Bai, B. (2007). Exploring Family Roles in Purchasing Decisions During Vacation Planning. Journal of Travel \& Tourism Marketing, 20(3-4), 107-125. doi: 10.1300/J073v20n03_08.

North, M. M., \& North, S. (2016). A Comparative Study of Sense of Presence of Traditional Virtual Reality and Immersive Environments. Australasian Journal of Information Systems, 20.

Palmer, A., \& McCole, P. (2000). The role of electronic commerce in creating virtual tourism destination marketing organisations. International Journal of Contemporary Hospitality Management, 12(3), 198-204. doi: 10.1108/09596110010320760.

Pantano, E., \& Servidio, R. (2011). An exploratory study of the role of pervasive environments for promotion of tourism destinations. Journal of Hospitality and Tourism Technology, 2(1), 50-65. doi: 10.1108/17579881111112412.

Pantelidis, C., tom Diek, M. C., Jung, T., \& Miller, A. (2018). Exploring tourist experiences of virtual reality in a rural destination: a place attachment theory perspective. $e$ Review of Tourism Research.

Patton, M. Q. (2002). Qualitative research and evaluation methods: Thousand Oaks, CA: Sage Publications.

Pearlman, D. M., \& Gates, N. A. (2010). Hosting Business Meetings and Special Events in Virtual Worlds: A Fad or the Future? Journal of Convention \& Event Tourism, 11(4), 247-265. doi: 10.1080/15470148.2010.530535. 
Pike, S., \& Ryan, C. (2004). Destination Positioning Analysis through a Comparison of Cognitive, Affective, and Conative Perceptions. Journal of Travel Research, 42(4), 333-342. doi: 10.1177/0047287504263029.

Quintal, V. A., Lee, J. A., \& Soutar, G. N. (2010). Risk, uncertainty and the theory of planned behavior: A tourism example. Tourism Management, 31(6), 797-805. doi: 10.1016/j.tourman.2009.08.006.

Riva, G., Mantovani, F., Capideville, C. S., Preziosa, A., Morganti, F., Villani, D., . . Alcaniz, M. (2007). Affective interactions using virtual reality: the link between presence and emotions. Cyberpsychol Behav, 10(1), 45-56. doi: 10.1089/cpb.2006.9993.

Ryan, C., \& Cave, J. (2016). Structuring Destination Image: A Qualitative Approach. Journal of Travel Research, 44(2), 143-150. doi: 10.1177/0047287505278991.

Schänzel, H. (2012). The inclusion of fathers, children and the whole family group in tourism research on families. In H. Schänzel, I. Yeoman \& E. Backer (Eds.), Family Tourism: Multidisciplinary Perspectives (Vol. 56, pp. 67-80): Channel View Publications.

Schänzel, H., \& Yeoman, I. (2015a). The Future of Family Tourism. Tourism Recreation Research, 39(3), 343-360. doi: 10.1080/02508281.2014.11087005.

Schänzel, H., \& Yeoman, I. (2015b). Trends in family tourism. Journal of Tourism Futures, 1(2), 141-147. doi: 10.1108/jtf-12-2014-0006.

Schänzel, H. A., \& Smith, K. A. (2014). The Socialization of Families Away from Home: Group Dynamics and Family Functioning on Holiday. Leisure Sciences, 36(2), 126143. doi: $10.1080 / 01490400.2013 .857624$.

Shaw, S. M. (1997). Controversies and contradictions in family leisure: an analysis of conflicting paradigms. Journal of Leisure Research, 29(1), 98-112.

Singh, N., \& Lee, M. J. (2009). Exploring Perceptions Toward Education in 3-D Virtual Environments: An Introduction to "Second Life". Journal of Teaching in Travel \& Tourism, 8(4), 315-327. doi: 10.1080/15313220903047896.

Slevitch, L., \& Sharma, A. (2008). Management of Perceived Risk in the Context of Destination Choice. International Journal of Hospitality \& Tourism Administration, 9(1), 85-103. doi: 10.1080/15256480801910574.

Stepchenkova, S., \& Mills, J. E. (2010). Destination Image: A Meta-Analysis of 2000-2007 Research. Journal of Hospitality Marketing \& Management, 19(6), 575-609. doi: 10.1080/19368623.2010.493071.

Steuer, J. (1992). Defining Virtual Reality: Dimensions Determining Telepresence. Journal of Communication, 42(4), 73-93.

Stevens, J. A., \& Kincaid, J. P. (2015). The Relationship between Presence and Performance in Virtual Simulation Training. Open Journal of Modelling and Simulation, 03(02), 41-48. doi: 10.4236/ojmsi.2015.32005.

Suh, K.-S., \& Lee, Y. E. (2005). The Effects of Virtual Reality on Consumer Learning: An Empirical Investigation. MIS Quarterly, 29(4), 673-697. Retrieved from http://www.jstor.org/stable/25148705

Therkelsen, A. (2010). Deciding on Family Holidays-Role Distribution and Strategies in Use. Journal of Travel \& Tourism Marketing, 27(8), 765-779. doi: 10.1080/10548408.2010.526895.

Thie, S., \& van Wijk, J. (1998). A General Theory on Presence. Proceedings of the Presence in Shared Virtual Environments Workshop, First International Workshop on Presence, Ipswich, Suffolk, UK.

Thomson, E. S., Laing, A. W., \& McKee, L. (2007). Family purchase decision making: exploring child influence behaviour. Journal of Consumer Behaviour, 6(4), 182-202. doi: $10.1002 / \mathrm{cb} .220$. 
Thornton, P. R., Shaw, G., \& Williams, A. M. (1997). Tourist group holiday decision-making and behaviour: The influence of children. Tourism Management, 18(5), 287-297.

tom Dieck, M. C., \& Jung, T. (2015). A theoretical model of mobile augmented reality acceptance in urban heritage tourism. Current Issues in Tourism, 1-21. doi: 10.1080/13683500.2015.1070801.

Tourism Australia. (2016). EXPERIENCE AUSTRALIA IN 360 . Retrieved from http://www.australia.com/en/things-to-do/aquatic/cardboard-app.html

Tussyadiah, I. P., Wang, D., \& Jia, C. (2016). Exploring the Persuasive Power of Virtual Reality Imagery for Destination Marketing. Tourism Travel and Research Association: Advancing Tourism Research Globally, 25. Retrieved from http://scholarworks.umass.edu/ttra/2016/Academic_Papers_Oral/25

Tussyadiah, I. P., Wang, D., Jung, T. H., \& tom Dieck, M. C. (2018). Virtual reality, presence, and attitude change: Empirical evidence from tourism. Tourism Management, 66, 140-154. doi: 10.1016/j.tourman.2017.12.003.

Villani, D., Repetto, C., Cipresso, P., \& Riva, G. (2012). May I experience more presence in doing the same thing in virtual reality than in reality? An answer from a simulated job interview. Interacting with Computers, 24(4), 265-272. doi: 10.1016/j.intcom.2012.04.008.

Vora, J., Nair, S., Gramopadhye, A. K., Duchowski, A. T., Melloy, B. J., \& Kanki, B. (2002). Using virtual reality technology for aircraft visual inspection training: presence and comparison. Applied Ergonomics, 33(6), 559-570. doi: 10.1016/S00036870(02)00039-X.

Walters, G., Sparks, B., \& Herington, C. (2012). The Impact of Consumption Vision and Emotion on the Tourism Consumer's Decision Behavior. Journal of Hospitality \& Tourism Research, 36(3), 366-389. doi: 10.1177/1096348010390815.

Wan, C.-S., Tsaur, S.-H., Chiu, Y.-L., \& Chiou, W.-B. (2007). Is the Advertising Effect of Virtual Experience Always Better or Contingent on Different Travel Destinations? Information Technology \& Tourism, 9(1), 45-54. doi: 10.3727/1098305077779637611.

Wang, K.-C., Hsieh, A.-T., Yeh, Y.-C., \& Tsai, C.-W. (2004). Who is the decision-maker: the parents or the child in group package tours? Tourism Management, 25(2), 183194. doi: 10.1016/s0261-5177(03)00093-1.

Wei, W. (2019). Research progress on virtual reality (VR) and augmented reality (AR) in tourism and hospitality. Journal of Hospitality and Tourism Technology. doi: 10.1108/jhtt-04-2018-0030.

Whittington, A. (2015). Family Vacation 2050: Socially and Technologically-Driven Scenarios of the Future of Family Travel, Recreation and Tourism. Tourism Recreation Research, 39(3), 379-396. doi: 10.1080/02508281.2014.11087007.

Wong, J.-Y., \& Yeh, C. (2009). Tourist hesitation in destination decision making. Annals of Tourism Research, 36(1), 6-23. doi: 10.1016/j.annals.2008.09.005.

Wu, M.-Y., Wall, G., Zu, Y., \& Ying, T. (2019). Chinese children's family tourism experiences. Tourism Management Perspectives, 29, 166-175.

Yang, M. J. H., Khoo-Lattimore, C., \& Yang, E. C. L. (2020). Three generations on a holiday: Exploring the influence of Neo-Confucian values on Korean Multigenerational Family vacation decision making. Tourism Management, 78, 104076.

Yung, R., \& Khoo-Lattimore, C. (2017). New realities: a systematic literature review on virtual reality and augmented reality in tourism research. Current Issues in Tourism, 22(17), 2056-2081. doi: 10.1080/13683500.2017.1417359.

Zhai, P. (1998). Get real: A philosophical adventure in virtual reality. Lanham, MD: Rowman \& Littlefield. 
Table 1. Profile of Sample Respondents

\begin{tabular}{lcc}
\hline Total sample $(\mathbf{n = 4 8})$ & No. & \% \\
\hline Gender & & \\
Parents & 12 & 50.00 \\
$\quad$ Male & 12 & 50.00 \\
$\quad$ Female & & \\
& & \\
Children & 8 & 33.33 \\
Male & 16 & 66.67 \\
Female & 48 & \\
& & \\
& & \\
Education Level & & 8.33 \\
Secondary & 2 & 29.67 \\
Undergraduate & 10 & 20.83 \\
Masters & 7 &
\end{tabular}

Age

\section{Parents}

37-44 years $\quad 12 \quad 50.00$

45-52 years $\quad 9 \quad 37.50$

$\begin{array}{lll}53 \text { years and older } & 3 & 12.50\end{array}$

\section{Children}

$\begin{array}{lrr}0-5 \text { years } & 3 & 12.50 \\ 6-11 \text { years } & 12 & 50.00 \\ 12-16 \text { years } & 7 & 29.17 \\ 17 \text { years and older } & 2 & 8.33\end{array}$

\section{Annual Household Income (AUD)}

$\begin{array}{lll}20,001-60,000 & 3 & 25.00 \\ 60,001-100,000 & 4 & 33.33 \\ 100,001-140,000 & 3 & 25.00 \\ 140,001 \text { and more } & 2 & 16.67\end{array}$

1 or 2 Income Household
1 Income Household
$4 \quad 33.33$
2 Income Household

$8 \quad 66.67$




\begin{tabular}{ll}
\hline Cognitive Image & Variety of fauna and flora \\
& Beautiful landscapes \\
Beautiful natural parks & Pleasant weather \\
Attractive beaches & Hospitable people \\
Many Opportunities for the adventurous \\
Peaceful place \\
Place to rest \\
A lot of cultural attractions \\
Interesting cultural activities \\
Nice to learn about local customs \\
Rich and varied gastronomy \\
Easy accessibility \\
Shopping facilities \\
Quality accommodation \\
Good value for money \\
Safe place \\
Sleepy-arousing \\
Distressing-relaxing \\
Gloomy-exciting \\
Unpleasant-pleasant \\
\hline
\end{tabular}

Figure 1. Criteria for Cognitive and Affective Classification. Source: Echtner and Ritchie (1993); del Bosque and Martin (2008); Kladou and Mavragani (2015). 


\begin{tabular}{|c|}
\hline $\begin{array}{c}\text { Vicarious } \\
\text { Experience }\end{array}$ \\
\hline Immersion
\end{tabular}$\rightarrow$\begin{tabular}{c|c|}
$\begin{array}{c}\text { Perceived } \\
\text { Financial Risk }\end{array}$ \\
Presence \\
Cognitive \\
$\begin{array}{c}\text { Perceived } \\
\text { Performance Risk }\end{array}$ \\
$\begin{array}{c}\text { Perceived Safety } \\
\text { Risk }\end{array}$ \\
Perceived \\
Risk
\end{tabular}$\rightarrow \begin{gathered}\text { Intention to } \\
\text { Visit }\end{gathered}$

Figure 2. Thematic map on the Influence of Virtual Reality on Perceived Risk. 


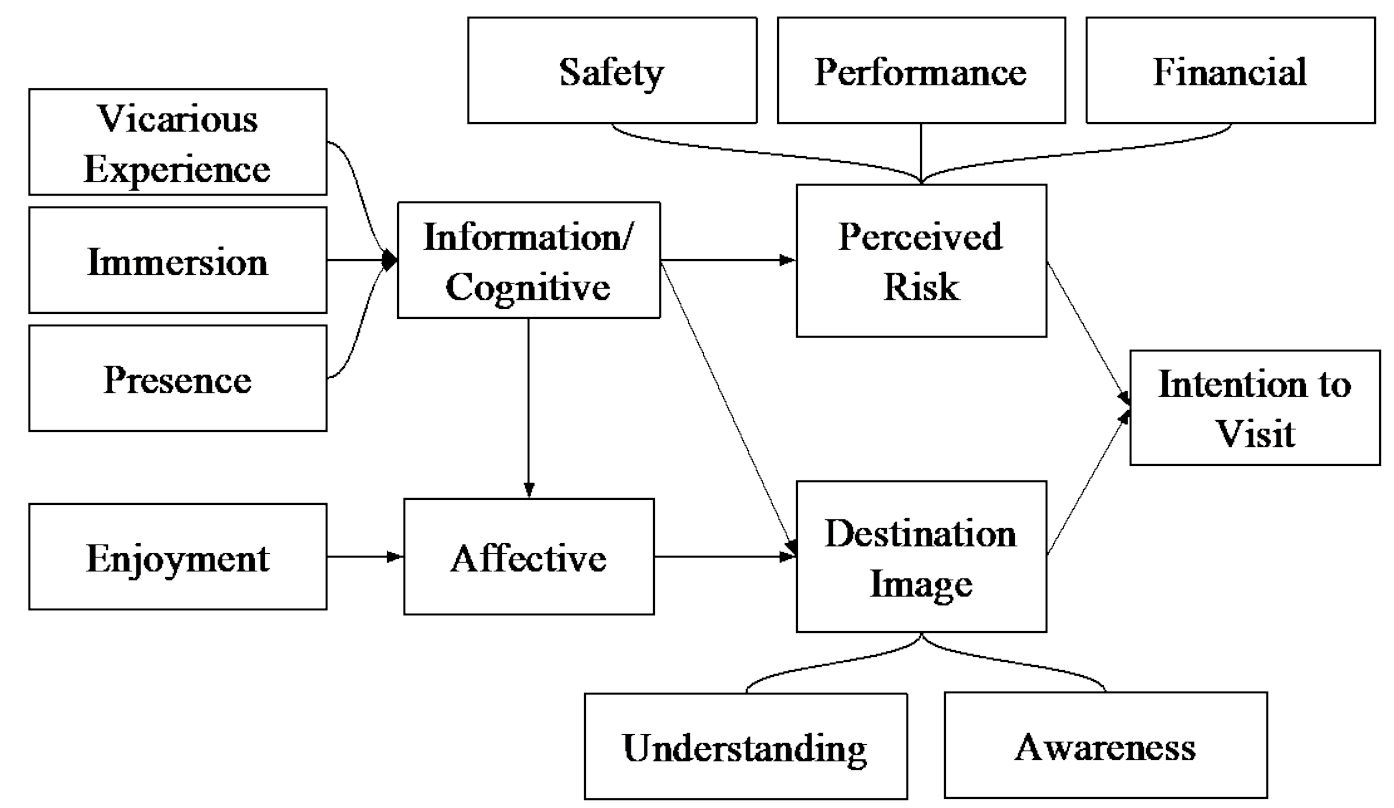

Figure 3. Theoretical Framework of Virtual Reality's Influence on Destination Selection Behaviour of Families. 


\section{Figure Captions:}

Figure 1. Criteria for Cognitive and Affective Classification. Source: Echtner and Ritchie (1993); del Bosque and Martin (2008); Kladou and Mavragani (2015).

Figure 2. Thematic map on the Influence of Virtual Reality on Perceived Risk.

Figure 3. Theoretical Framework of Virtual Reality's Influence on Destination Selection Behaviour of Families. 